\title{
Biofuels and biochars production from agricultural biomass wastes by thermochemical conversion technologies: Thermogravimetric analysis and pyrolysis studies
}

\author{
M. Y. GUIDA ${ }^{1 *}$ (1), B. REBBAH ${ }^{1}$, N. ANTER ${ }^{1}$, A. MEDAGHRI-ALAOUI $^{1,2}$, \\ E. M. RAKIB ${ }^{1,3}$ and A. HANNIOUI ${ }^{1,2}$
}

${ }^{1}$ Organic Chemistry and Analytical Laboratory (LCOA), Faculty of Sciences and Techniques (FST), University of Sultan Moulay Slimane (USMS), 23000 Béni-Mellal, Morocco

${ }^{2}$ Department of Chemistry and Environment, Faculty of Sciences and Techniques (FST), University of Sultan Moulay Slimane (USMS), 23000 Béni-Mellal, Morocco

${ }^{3}$ Higher School of Technology, EST-Fkih ben Saleh, University of Sultan Moulay Slimane (USMS), 23000 Béni-Mellal, Morocco

\section{ORIGINAL RESEARCH PAPER}

Received: April 18, 2021 • Accepted: July 11, 2021

Published online: August 13, 2021

(C) 2021 The Author(s)

\begin{abstract}
In this paper, thermal degradation (TGA) and pyrolysis studies of sunflower shell biomass (SSB), eucalyptus biomass (EB), wheat straw biomass (WSB), and peanut shell biomass (PSB) were carried out using the thermogravimetric analysis and stainless steel tubular reactor. Thermal degradation of all biomass wastes was examined at a heating rate of $10^{\circ} \mathrm{C} / \mathrm{min}$ in nitrogen atmosphere between 20 and $800^{\circ} \mathrm{C}$. Experiments of pyrolysis were carried out in a tubular reactor from 300 to $700^{\circ} \mathrm{C}$ with a heating rate of $10^{\circ} \mathrm{C} / \mathrm{min}$, a particle size of $0.1-0.3 \mathrm{~mm}$ and nitrogen flow rate of $100 \mathrm{~mL} \cdot \mathrm{min}^{-1}$, which the aim to study how temperature affects liquid, solid, and gas products. The results of this work showed that three stages have been identified in the thermal decomposition of SSB, EB, WSB, and PSB wastes. The first stage occurred at $120-158^{\circ} \mathrm{C}$, the second stage, which corresponds to hemicellulose and cellulose's degradation, occurred in temperatures range from 139 to $480{ }^{\circ} \mathrm{C}$ for hemicellulose, and from 233 to $412^{\circ} \mathrm{C}$ for cellulose,
\end{abstract}

*Corresponding author. E-mail: myassineguida@gmail.com; guida.yassine@gmail.com 
while the third stage occurred at $534-720^{\circ} \mathrm{C}$. It was concluded that temperature has a significant effect on product yields. The maximum of bio-oil yields of $37.55,30.5,46.96$, and $50.05 \mathrm{wt} \%$ for WSB, PSB, SSB, and $\mathrm{EB}$, were obtained at pyrolysis temperature of $500^{\circ} \mathrm{C}$ (SSB, PSB, and WSB) and $550{ }^{\circ} \mathrm{C}(\mathrm{EB})$. Raw biomass, solid and liquid products obtained were characterized by elemental analysis, Fourier transformed infrared spectroscopy (FT-IR), nuclear magnetic resonance spectroscopy (NMR), and x-ray diffraction (XRD). The analysis of solid and liquid products showed that bio-oils and bio-chars from agricultural biomass wastes could be prospective sources of renewable fuels production and value added chemical products.

\section{KEYWORDS}

agricultural biomass, pyrolysis, thermogravimetric analysis, bio-fuels

\section{INTRODUCTION}

During the last two decades, the world has experienced a big change and major transformation (Malakar et al., 2021). The over-exploitation of fossil fuels and environmental degradation problems have increased for many years. Industrial revolution and anthropogenic activities have left their impact on the countries (Dostal and Ladanyi, 2018; Shang et al., 2013; Xiao et al., 2017). As mentioned in Fig. 1, from 2000 to 2019, carbon dioxide $\left(\mathrm{CO}_{2}\right)$ and methane $\left(\mathrm{CH}_{4}\right)$ emissions from different origins have led to finding sustainable low carbon energy sources to reduce and moderate environment problems and global oil demand. As can be seen in Fig. 1, lignocellulosic biomass has been shown as one of the specified replacements and solutions to fossil resource by advantage of its large quantity, low nitrogen and sulfur contents (typically $0.1 \%$ sulfur and $0.3 \%$ nitrogen), carbon neutrality, environment-friendly character and no emissions of $\mathrm{CO}_{2}$. Since the year 2000, biomass has gained a lot of attention, and has been analysed in several researches, with the aim to use it as a renewable source of energy utilizable in various domains and fields

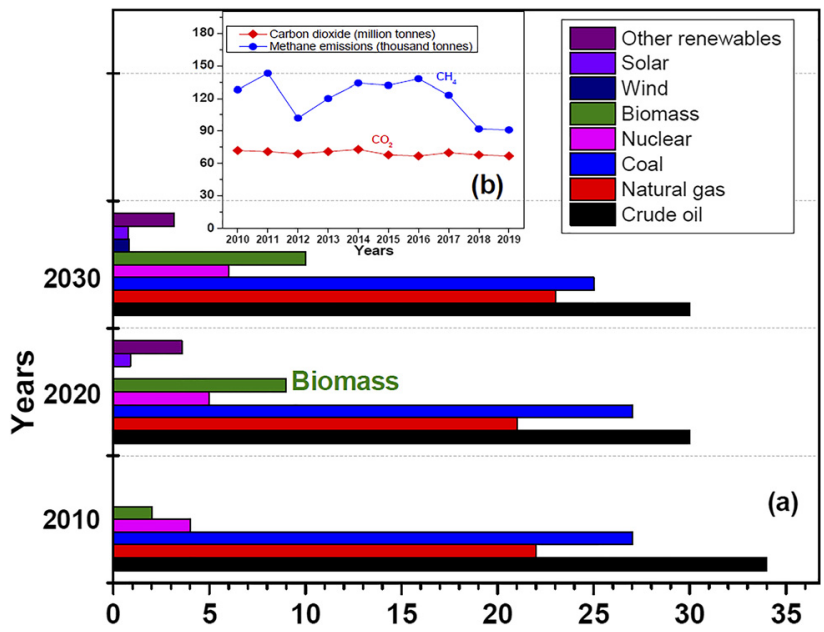

Fig. 1. (a); Projected global energy demand to 2030, (b); Carbon dioxide and methane emissions (Shell sustainability report) 
(Bayramzadeh and Aghaei, 2020; Benedek et al., 2018; Yanting and Liyun, 2011). From the literature, it can be found that there are several types of lignocellulosic biomass which are composed from hemicellulose, cellulose and lignin, like agricultural biomass, organic waste, energy crops, forest residues, etc. (Erdil and Erbijik, 2015; Khan et al., 2020; Searcy and Flynn, 2010). Because of its high energy content, high abundance in agricultural growing countries, and high cellulose, hemicellulose and lignin content, agricultural biomass wastes have attracted a lot of scientists, which the aim to produce biofuels (bio-oil, bio-char and gas products) from several and different types of agricultural biomass waste (Guida et al., 2020; Meshitsuka and Isogai, 1996; Worasuwannarak et al., 2007).

Thermochemical conversion technology presents a good and viable option for the valorization of several type of lignocellulosic biomass (constituted from cellulose, hemicellulose and lignin). As can be seen in Fig. 2, pyrolysis is considered one of the main common thermochemical conversion methods that can produce various valuable products, such as: bio-char product, bio-oil product, MHV (medium heating value) fuel gas and LHV (lower heating value) fuel gas. This method is called pyrolysis; it is based on chemical decomposition of biomass under effect of temperature 'heat' -, and without oxygenated environment (Khan et al., 2020; Minkova et al., 2001; Uzun et al., 2007). This method has been investigated recently. It has been referred to a method, in which biomass, such as waste, is thermally decomposed at ordinary and reasonable temperature in the range of 150 and $900{ }^{\circ} \mathrm{C}$, in the absence of oxygen and air (Huang et al., 2016; Kumar et al., 2020; Ozbay et al., 2001; Zabaniotou, 2010). As mentioned in Fig. 3, which presents documents published on biomass and pyrolysis of biomass, it can be seen that in the last twenty years, from 2000 to 2020, several researches have been made to study and investigate the pyrolysis of several types of biomass waste. The evolution of published documents increased between 2000 and 2020, there was a shift increase for biomass and pyrolysis of biomass published documents. Figure 3 shows that engineering, environmental science, energy, chemical engineering, and chemistry are the domains which use pyrolysis of agricultural biomass between 2000 and 2020. At international scale, the greatest countries which made their researches on pyrolysis of agricultural biomass in the form of clusters are: China, United States, United Kingdom, India, and Germany, as seen in Fig. 4. Morocco is one of the countries which are interested in thermochemical valorization of biomass waste.

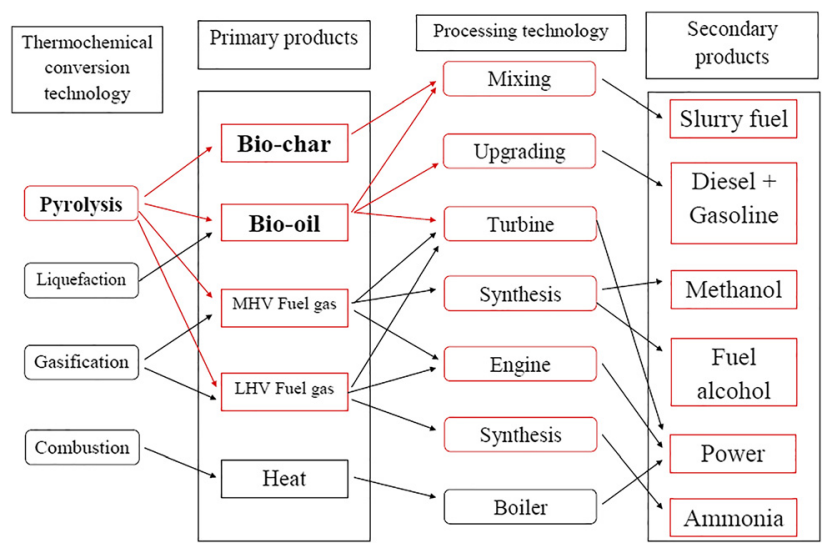

Fig. 2. Primary and secondary products from thermochemical conversion 


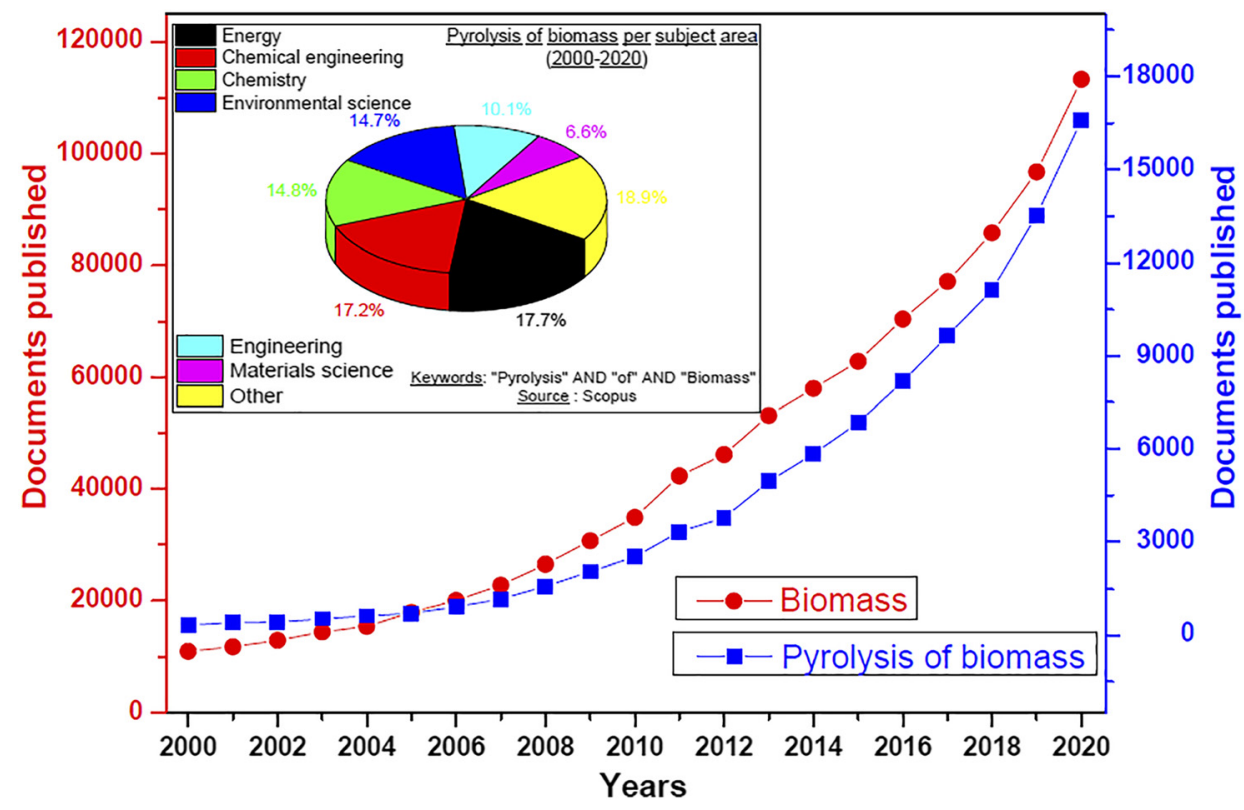

Fig. 3. Documents published on biomass and pyrolysis of biomass during 2000-2020 period. (Keywords: 'Biomass', 'Pyrolysis' AND 'of AND 'biomass').

(Source: Scopus)

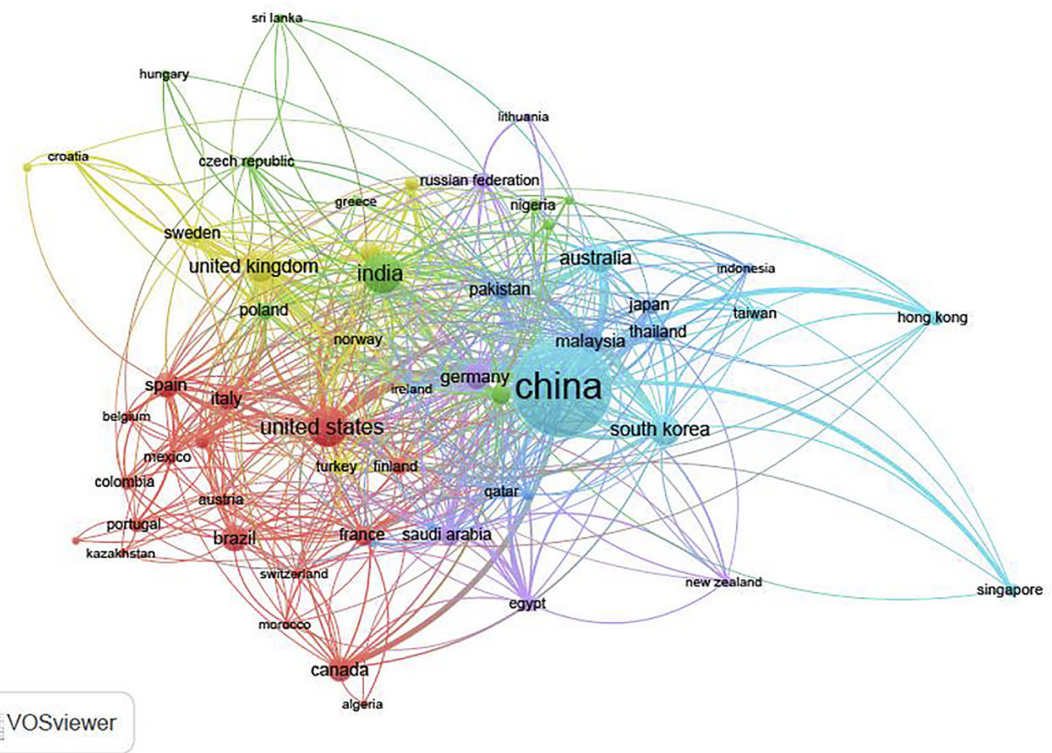

Fig. 4. Network of cooperation based on co-authorship between countries from 2000 to 2020. (Source: Scopus) 
Moroccan cluster contains; United States, Canada, France, Brazil, Italy, Spain, Morocco and other countries, as mentioned in Fig. 4.

Several studies have been carried out by a number of researchers, on pyrolysis of agricultural biomass waste, such as rice straw (Park et al., 2014), olive bagasse (Sensoz et al., 2006), lignocellulosic biomass (Kumar et al., 2020; Huang et al., 2016), palm oil waste (Yang et al., 2006), sugar cane bagasse (Guida et al., 2017; Parthasarathy and Narayanan, 2015) in various types of reactors. Their results have showed that pyrolysis of biomass differed from one type to another; thermal decomposition of biomass depends on its compositions of cellulose, hemicellulose and lignin, and its ultimate characteristics. Pimenta et al. (2018), have studied pyrolysis of two types of wood; trunk and stump woods, their aim was studied light and heavy bio-oils products (Pimenta et al., 2018). They have showed that liquid products obtained from stump wood were $31.6 \%$ light and $11.8 \%$ heavy, while liquid products obtained from trunk wood were $34.1 \%$ light and $13 \%$ heavy. Heo et al. (2010), have worked on fast pyrolysis process of sawdust waste in fluidized bed reactor, their result showed a maximum of bio-oil $58.1 \%$ at $450{ }^{\circ} \mathrm{C}$ (Heo et al., 2010). Park et al. (2014), have studied slow pyrolysis of rice straw at various pyrolysis' temperatures ranging from 300 to $700{ }^{\circ} \mathrm{C}$, with a heating rate of $10^{\circ} \mathrm{C} / \mathrm{min}$. They have obtained $43 \%$ of bio-oil product and $39 \%$ of bio-char product at optimal temperature of $500{ }^{\circ} \mathrm{C}$ (Park et al., 2014). Balagurumurthy et al. (2015), have studied pyrolysis of rice straw in $\mathrm{N}_{2}$ and $\mathrm{H}_{2}$ atmospheres; they showed that bio-oils obtained were $12.8 \%$ and $31 \%$ under $\mathrm{H}_{2}$ and $\mathrm{N}_{2}$ atmosphere at $700{ }^{\circ} \mathrm{C}$. They have found that the higher percentage of liquid product was obtained under the nitrogen atmosphere than hydrogen atmosphere (Balagurumurthy et al. 2015).

Liew et al. (2021), have worked on synergetic effects of catalytic co-pyrolysis of corn cob and HDPE (high-density polyethylene) waste; they showed that corn cob biomass waste presents a good opportunity to have bio-oil and to add a value product from pyrolysis of corn cob biomass (Liew et al., 2021). Klaas et al. (2020), studied effects of torrefaction pre-treatment on pyrolysis of corn cobs employing a continuous fluidized bed reactor, they have found the greatest liquid product yield of $51.7 \%$ achieved at $450^{\circ} \mathrm{C}$ (Klaas et al., 2020). Other works (Chen et al., 2014; Dai et al., 2019; Duan et al., 2020; Ioannidou et al., 2009; Mullen et al., 2010; Phuakpunk et al., 2020; Watt et al., 2020), have showed that wastes in general and especially agricultural biomass wastes offer a good opportunity to generate a new renewable source of energy.

This study presents the thermochemical valorization of agricultural biomass wastes, such as: sunflower shell biomass, eucalyptus biomass, wheat straw biomass, and peanut shell biomass, to provide comprehensive information on the chemical properties, carbon distribution and energy yields of solid 'biochar' and liquid 'bio-oil' products. The objective is to perform and carry out experiments for thermogravimetric analysis and pyrolysis of agricultural biomass wastes in a rheometrix scientific analyzer, in a stainless steel tubular reactor and to study the influence of biomasses' temperature on pyrolysis product yields. This paper should be of interest to readers in the area of valuation of agricultural biomass waste and entering in the renewable energy framework.

\section{MATERIALS AND METHODOLOGY}

\section{Materials}

The agricultural biomass wastes (in dry powder form) used in this study have been collected from Meknes and Béni-Mellal cities, Morocco. All type of biomasses samples collected were 
dried in the sun (air-dried) for 15 days, then grounded and sieved which the aim to obtain uniform matters and samples of average particle size between $0.1 \mathrm{~mm}$ and $0.3 \mathrm{~mm}$.

\section{Characterization methods}

As described below, several physicochemical and analytical procedures were used to determine the various properties of agricultural biomass wastes and different products obtained from pyrolysis.

Thermal analysis: sunflower shell, eucalyptus, wheat straw and peanut shell biomasses waste samples were exposed to thermogravimetric analysis in nitrogen's inert atmosphere $\left(\mathrm{N}_{2}\right)$. Rheometrix Scientific STA 1500 analyzer was used to evaluate and trace the sample mass change with temperature (TG) over the pyrolysis reaction course. TG and DTG (derivative thermogravimetry) curves were obtained at a heating rate of $10^{\circ} \mathrm{C} / \mathrm{min}$, between 20 and $800^{\circ} \mathrm{C}$. Nitrogen gas has been used as an inert purge gas to relocate air in the pyrolysis zone during registration and to prevent unnecessary oxidation of the samples. A flow rate of around $60 \mathrm{~mL} / \mathrm{min}$ was fed to the system from a point below the sample and a purge time of $60 \mathrm{~min}$. All quantities and masses used in this study average $20 \mathrm{mg}$. The experiments' reproducibility was up to standard and the experimental records presented corresponding to the different operating conditions were the mean values of run carried out three times. Biomass' thermal decomposition is a heterogeneous reaction, it can be modelled as:

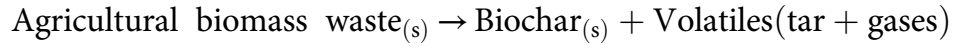

Elemental composition: proximate and ultimate analyses were accomplished in accordance with ASTM (American Society for Testing and Materials) standards (CHNS/O) analyzer and the weight percent of oxygen was obtained by difference. Agricultural samples' HHV was calculated with the formula ( $\mathrm{HHV}=0.4373 \mathrm{C}-1.671$ ) (Tillman, 1978). The O/C ratio, H/C ratio and empirical formula were calculated from elemental analysis.

${ }^{1} H^{\prime} N M R, F T-I R$ and XRD analyses of bio-oil and bio-char products: bio-oil and bio-char products obtained at temperature of 500 and $550{ }^{\circ} \mathrm{C}$, and at a heating rate of $10^{\circ} \mathrm{C} / \mathrm{min}$ were selected for characterization. Bio-oils products were diluted with $\mathrm{CDCL}_{3}$ (Deuterated chloroform). ${ }^{1} \mathrm{H}$ 'NMR spectra have been registered on BrukerSpectro instruments. FT-IR spectra were registered on a Perkin-Elmer 1760 FT-IR spectrometer over a range of 4,000 and $400 \mathrm{~cm}^{-1}$. XRD analyses were made on Bruker D8 advance X-ray diffractometer. Diffraction patterns in the 2$80^{\circ}$ regions have been registered with a step time of $4 \mathrm{~s}$.

\section{Pyrolysis apparatus and procedure}

As can be seen in Fig. 5, agricultural biomass waste samples were pyrolyzed in a stainless steel tubular reactor, heated with a furnace tubular type R 50/250/12. Sunflower shell, eucalyptus, wheat straw and peanut shell biomasses pyrolysis was implemented three times (experimental error varies from 0.5 to $0.9 \mathrm{wt} \%$ ) to improve the results' profitability and reproducibility. The product yields are mean values of three equivalent experiments. As mentioned in Fig. 5, a sample of $40 \mathrm{~g}$ of biomass waste was placed into the reactor, nitrogen gas was introduced for 15 min to remove air in the reactor and experiments were carried out with a final temperature $\left(300,350,400,450,500,550,600,650\right.$ and $\left.700{ }^{\circ} \mathrm{C}\right)$, heating rate of $10^{\circ} \mathrm{C} / \mathrm{min}$, nitrogen flow rate of $100 \mathrm{~mL} / \mathrm{min}$, particle size of $0.1-0.3 \mathrm{~mm}$ and held for $15 \mathrm{~min}$ at the final temperature. Biochar products in the reactor were weighed and the gaseous product plus losses yields were 


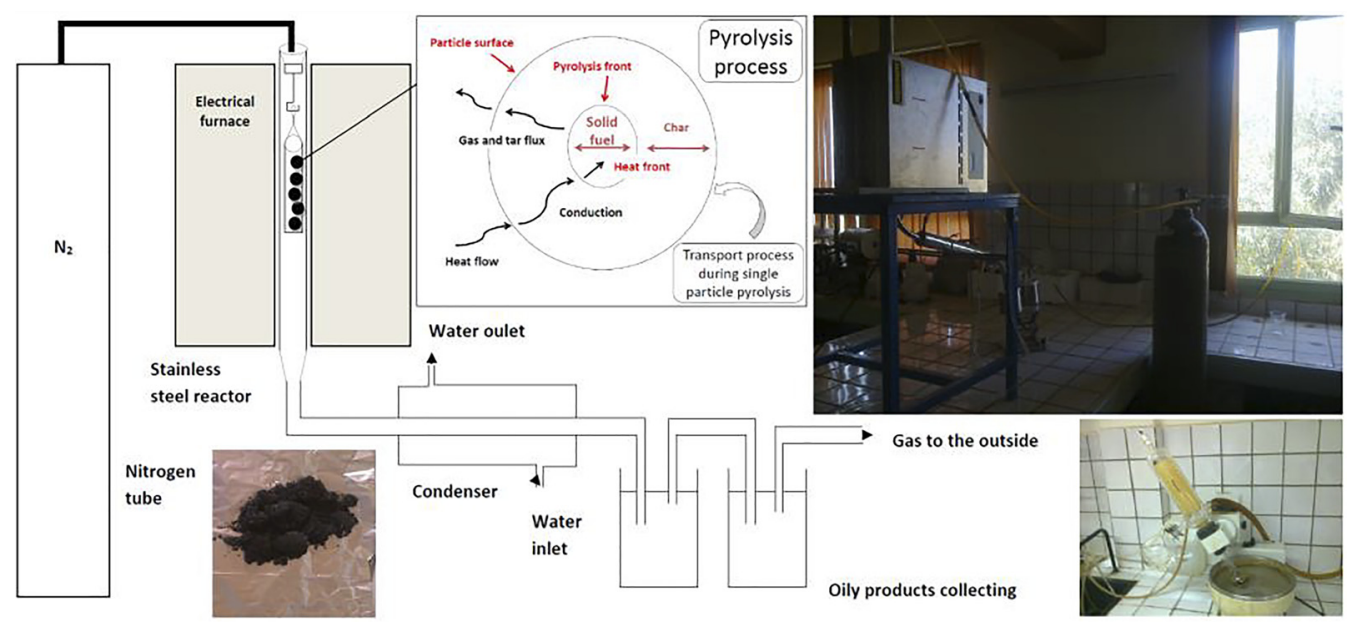

Fig. 5. Apparatus and devices used in the pyrolysis experiments

calculated by determining the mass difference. Bio-oil products were collected in two collecting containers with dichloromethane as solvent. The solvent was separated from bio-oil and was weighed, and its yield was determined.

1. Bio-oil product yield $(\mathrm{wt} \%)=($ bio-oil collected/initial biomass $) * 100$

2. Bio-char product yield $(\mathrm{wt} \%)=$ (bio-char collected/initial biomass) ${ }^{*} 100$

3. Gas and losses yield $(w t \%)=100-((1)+(2))$

4. Conversion degree $($ wt $\%)=(($ initial biomass - bio-char collected $) /$ initial biomass $){ }^{*} 100$

\section{RESULTS AND DISCUSSION}

\section{Four types of biomass' characterization}

Table 1 shows the main important characteristics of sunflower shell biomass, eucalyptus biomass, wheat straw biomass, and peanut shell biomass wastes, such as: elemental analysis, proximate analysis and chemical analysis. All results have been presented as mass percentage. From the proximate analysis, the SSB, EB, WSB and PSB wastes have a volatile matter percentage higher than $70 \mathrm{wt} \%$, which indicate that all four biomasses samples can produce condensable vapors during pyrolysis experiments. A high volatile matter's content is desirable for the pyrolysis process (Huang et al., 2016). The volatile matter percentages were 74.11, 73.23, 78.24 and $76.53 \mathrm{wt} \%$ for PSB, WSB, EB and SSB, respectively. The ash percentages of sunflower shell and wheat straw biomasses were 6.5 and $5.91 \mathrm{wt} \%$, respectively, while, eucalyptus and peanut shell biomass have a low percentage, they were 2.86 and $3.75 \mathrm{wt} \%$. Several authors have shown that ash content varies depending on material's nature. It was found to be $8 \mathrm{wt} \%$ for coal, $4 \mathrm{wt} \%$ for wheat straw, $4.5 \mathrm{wt} \%$ for switchgrass and $6 \mathrm{wt} \%$ for barley straw (Akhtar and Saidina Amin, 2012; Huang et al., 2016; Mohan et al., 2006). They have shown that high ash content impact the higher heating value (HHV) because the inorganic materials that are in ash have the 
Table 1. Characteristics of SSB, EB, WSB and PSB biomasses

\begin{tabular}{|c|c|c|c|c|c|}
\hline Main characteristic & & SSB (wt\%) & $\mathrm{EB}(\mathrm{wt} \%)$ & WSB (wt\%) & PSB (wt\%) \\
\hline \multirow{4}{*}{$\begin{array}{r}\text { Proximate } \\
\text { analysis }\end{array}$} & Moisture & 7.84 & 10.69 & 7.51 & 6.91 \\
\hline & $\begin{array}{l}\text { Volatile } \\
\text { matter }\end{array}$ & 76.53 & 78.24 & 73.23 & 74.11 \\
\hline & Ash & 6.5 & 2.86 & 5.91 & 3.75 \\
\hline & $\begin{array}{c}\text { Fixed } \\
\text { carbon }^{(a)}\end{array}$ & 9.13 & 8.21 & 13.35 & 15.23 \\
\hline \multirow{5}{*}{$\begin{array}{r}\text { Elemental } \\
\text { analysis }\end{array}$} & $\mathrm{C}$ & 41.84 & 48.18 & 39.07 & 36.12 \\
\hline & $\mathrm{H}$ & 6.08 & 7.06 & 5.37 & 5.2 \\
\hline & $\mathrm{N}$ & 1.8 & 0.6 & 0.63 & 0.6 \\
\hline & S & 0.45 & 0.48 & 0.26 & 0.37 \\
\hline & $\mathrm{O}^{(\mathrm{a})}$ & 49.83 & 43.68 & 54.67 & 57.71 \\
\hline \multirow{3}{*}{$\begin{array}{l}\text { Chemical } \\
\text { analysis }\end{array}$} & Hemicellulose & 35.20 & 30.02 & 31.05 & 29.15 \\
\hline & Cellulose & 41.45 & 45.16 & 33.16 & 30.81 \\
\hline & Lignin & 18.5 & 20.87 & 20.6 & 25.95 \\
\hline $\begin{array}{l}\mathrm{H} / \mathrm{C} \text { molar } \\
\text { proportion }\end{array}$ & & 1.74 & 1.75 & 1.65 & 1.72 \\
\hline $\begin{array}{l}\text { Empirical } \\
\text { formula }\end{array}$ & & $\mathrm{CH}_{1.74} \mathrm{O}_{0.89} \mathrm{~N}_{0.03}$ & $\mathrm{CH}_{1.75} \mathrm{O}_{0.67} \mathrm{~N}_{0.01}$ & $\mathrm{CH}_{1.64} \mathrm{O}_{1.04} \mathrm{~N}_{0.01}$ & $\mathrm{CH}_{1.72} \mathrm{O}_{1.19} \mathrm{~N}_{0.01}$ \\
\hline $\mathrm{HHV}(\mathrm{MJ} / \mathrm{kg})^{(\mathrm{c})}$ & & 16.62 & 19.39 & 15.41 & 14.12 \\
\hline
\end{tabular}

(a) By difference.

(b) Calculated from elemental analysis.

(c) Calculated by formula; HHV $=0.4373$ C-1.6701 (Tillman, 1978).

capability to affect the biomass pyrolysis mechanism. Moisture content in samples was 7.84, 10.69, 7.51 and $6.91 \mathrm{wt} \%$ for SSB, EB, WSB and PSB, respectively. It has been known that for pyrolysis process, the moisture percentage in holocellulosic biomass waste should be underneath 10 wt\% (Asadullah et al., 2007; Sensoz et al., 2006).

From the elemental analysis, all four types of biomass wastes have 41.81, 48.18, 39.07 and $36.12 \mathrm{wt} \%$ of carbon for SSB, EB, WSB and PSB, respectively. They have 6.08, 7.06, 5.37 and $5.2 \mathrm{wt} \%$ of hydrogen. While they have $49.83,43.68,54.67$ and $57.71 \mathrm{wt} \%$ of oxygen, respectively. Elemental analysis shows that all four types of biomasses have low sulfur and nitrogen contents; they were $0.45,0.48,0.26$ and 0.37 wt\% of sulfur for SSB, EB, WSB and PSB, respectively. Nitrogen contents was $0.6,0.63,0.6$ and $1.8 \mathrm{wt} \%$ for PSB, WSB, EB and SSB, respectively. These types of biomass with low nitrogen and sulfur contents can be a good nominee for thermochemical conversion process. Low sulfur and nitrogen contents in biomass imply that they release few amounts of $\mathrm{NO}_{\mathrm{x}}$ and $\mathrm{SO}_{\mathrm{x}}$ compounds during pyrolysis (Guida et al., 2020; Situmorang et al., 2021; Xin et al., 2020).

From Table 1, it can be seen that hemicellulose, cellulose and lignin contents vary depending on the type of biomass. They were $35.20,30.02,31.05$ and $29.15 \mathrm{wt} \%$ of hemicelluloses and cellulose contents were 41.45, 45.16, 33.16 and $30.81 \mathrm{wt} \%$, for SSB, EB, WSB, and PSB, respectively. While lignin contents were 18.5, 20.87, 20.6 and $25.95 \mathrm{wt} \%$, respectively. Sunflower shell, eucalyptus, wheat straw and peanut shell biomasses waste are biomasses which contain hemicellulose, cellulose and lignin. These biomasses types present a good opportunity for a renewable energy source through thermochemical conversion, such as pyrolysis. 


\section{Thermal degradation of agricultural biomasses}

The TG and DTG curves of sunflower shell, eucalyptus, wheat straw and peanut shell biomasses samples at a heating rate of $10{ }^{\circ} \mathrm{C} / \mathrm{min}$ are presented in Fig. 6 . It can be seen that pyrolysis profiles under inert atmosphere (TG and DTG) of all biomasses samples obtained are similar to those described by several authors that studied thermogravimetric analysis of various type of biomasses (Biswas et al., 2017; Guida et al., 2019; Liew et al., 2021; Rout et al., 2016; Sensoz and Angin, 2008). As known, eucalyptus, peanut shell, wheat straw and sunflower shell wastes are biomasses and they are mainly composed from three components that are hemicellulose, cellulose and lignin, with other extractives and compounds in small amounts. As can be seen in Figs 7 and 8, each pseudo-component has a dissimilar degradation temperature region.

From Fig. 6, three stages can be identified for agricultural biomasses thermal degradation. The first stage is linked to the moisture evaporation and some light volatile compounds. It occurs in the thermal range from ambient temperature $25^{\circ} \mathrm{C}$ to around $120-160^{\circ} \mathrm{C}$. The mass losses in the first stage were approximately $7.79,10.25,7.3$, and $6.51 \%$ for SSB, EB, WSB and PSB samples, which confirm results obtained for moisture from proximate analysis that were $6.91,7.51,10.69$, and $7.84 \%$ for PSB, WSB, EB, and SSB, respectively. The main volatilization process has occurred in the second stage which is called an active stage (or active zone). It has been ranged from 139 to $174{ }^{\circ} \mathrm{C}$ to around $380-412^{\circ} \mathrm{C}$. The mass losses of the main pyrolysis were about $72.66,71.93,68.93$ and $55.3 \%$. After the main degradation pyrolytic process (devolatilization), a continuous degradation mainly up to $720^{\circ} \mathrm{C}$ attributed to lignin's degradation and some of carbonaceous compound in the residues. These results are in concordance with several studies which have been made on pyrolysis of various lignocellulosic biomass (Demiral and Ayan 2011; Guida, 2017; Guida et al., 2015, 2018; Varma et al., 2019). After all these three stages, a slight mass loss has been seen between 700 and $800{ }^{\circ} \mathrm{C}$; it can be attributed to the inorganic material degradation. Residual masses at $800{ }^{\circ} \mathrm{C}$ were 25.65 ,

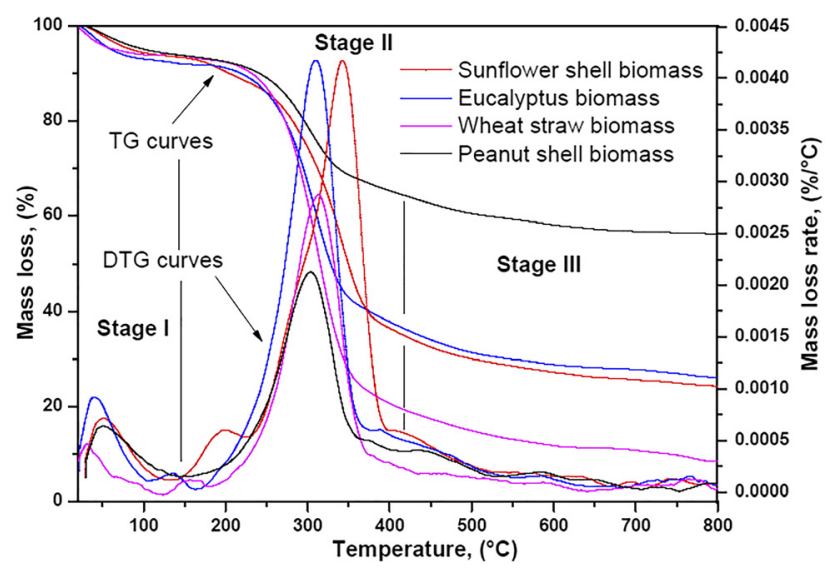

Fig. 6. Thermogravimetric and derivative thermogravimetric curves of SSB, EB, WSB and PSB biomass wastes at $10^{\circ} \mathrm{C} / \mathrm{min}$ 


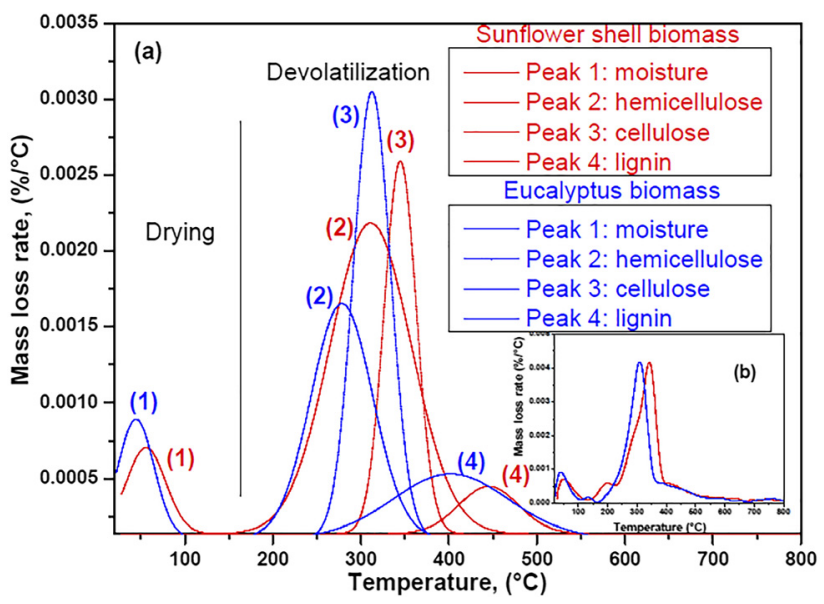

Fig. 7. (a); Pyrolysis peaks of SSB and EB's components, (b); Derivative thermogravimetric curves of SSB and EB biomasses

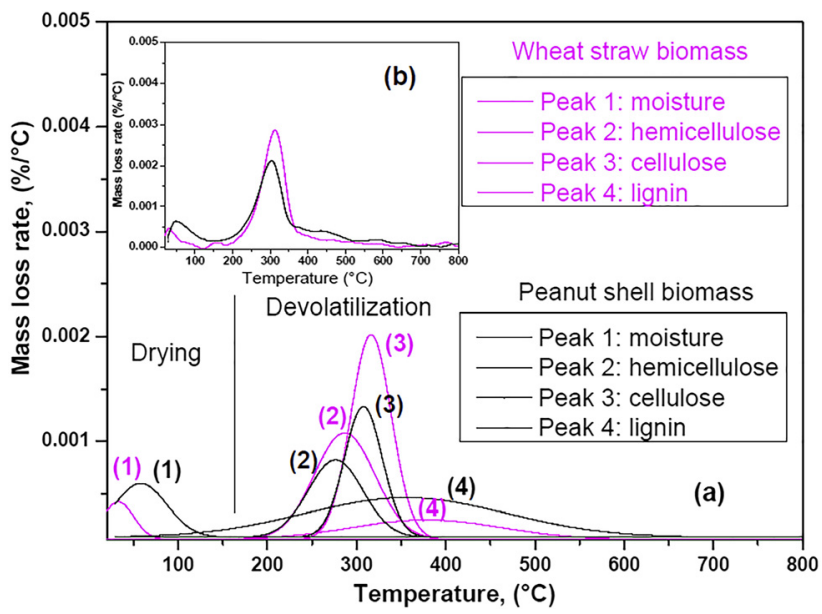

Fig. 8. (a); Pyrolysis peaks of WSB and PSB's components, (b); Derivative thermogravimetric curves of WSB and PSB biomasses

$26.49,15.38$, and $58.6 \%$ of the initial mass for sunflower shell, eucalyptus, wheat straw, and peanut shell biomasses samples.

As can be seen in Figs 7 and 8, DTG curve could be divided into four individual pyrolysis peaks, which correspond to the main sample's composition. In this study, DTG curve has been divided into four peaks that correspond to moisture, hemicellulose, cellulose and lignin in agricultural biomass wastes. Table 2 shows the initial temperature $\left(T_{i}\right)$, the maximal temperature $\left(\mathrm{T}_{\max }\right)$, and the final temperature $\left(\mathrm{T}_{\mathrm{f}}\right)$ of different stages. The first stage corresponds to the moisture evaporation that occurred at $120-158^{\circ} \mathrm{C}$. The second stage corresponds to the 
degradation and decomposition of hemicellulose and cellulose; it was found that hemicellulose decomposed in the temperature range from 139 to $480^{\circ} \mathrm{C}$, while cellulose has been decomposed in the temperature range from 233 to $412^{\circ} \mathrm{C}$. Finally, the third stage which refers to lignin compound, it has been decomposed in the temperature range of $534-720^{\circ} \mathrm{C}$. These results obtained were in coincidence with other researches (Chen et al., 2015; Kumar et al., 2018). Chen et al. (2015), have established that temperature degradation of biomass constituents, such as hemicellulose, cellulose and lignin for all five type of lignocellulosic biomasses were $141-304{ }^{\circ} \mathrm{C}$, $276-407^{\circ} \mathrm{C}$ and $380-588^{\circ} \mathrm{C}$ at $10^{\circ} \mathrm{C} / \mathrm{min}$, respectively. Kumar et al. (2018), stated that the most important active pyrolysis range is from 160 to $520^{\circ} \mathrm{C}$. The results obtained from this study show that thermochemical decomposition of agricultural biomass differs from one biomass type to another. Figure 9 presents conversion degree of SSB, EB, WSB and PSB wastes. As can be seen, conversion degree and thermal decomposition of all biomasses is different; this result can be explained by the different composition of biomass and the different amounts of proximate and ultimate analyses.

Table 2. Different temperature values of SSB, EB, PSB and WSB at heating rate of $10^{\circ} \mathrm{C} / \mathrm{min}$

\begin{tabular}{lcccc}
\hline & Stage I & \multicolumn{2}{c}{ Stage II } & Stage III \\
\cline { 2 - 3 } Samples & $\begin{array}{c}\text { Moisture } \\
\mathrm{T}_{\mathrm{i}} / \mathrm{DTG}_{\max } / \mathrm{T}_{\mathrm{f}}\end{array}$ & $\begin{array}{c}\text { Hemicellulose } \\
\mathrm{T}_{\mathrm{i}} / \mathrm{DTG}_{\max } / \mathrm{T}_{\mathrm{f}}\end{array}$ & $\begin{array}{c}\text { Cellulose } \\
\mathrm{T}_{\mathrm{i}} / \mathrm{DTG}_{\max } / \mathrm{T}_{\mathrm{f}}\end{array}$ & $\begin{array}{c}\text { Lignin } \\
\mathrm{T}_{\mathrm{i}} / \mathrm{DTG}_{\max } / \mathrm{T}_{\mathrm{f}}\end{array}$ \\
\hline Sunflower shell biomass (SSB) & $28 / 55 / 126$ & $145 / 314 / 480$ & $282 / 345 / 412$ & $342 / 449 / 534$ \\
Eucalyptus biomass (EB) & $22 / 45 / 120$ & $150 / 310 / 396$ & $280 / 314 / 390$ & $213 / 405 / 592$ \\
Peanut shell biomass (PSB) & $25 / 59 / 158$ & $174 / 278 / 372$ & $233 / 307 / 380$ & $80 / 365 / 720$ \\
Wheat straw biomass (WSB) & $20 / 34 / 121$ & $139 / 282 / 378$ & $234 / 317 / 386$ & $196 / 392 / 546$ \\
\hline
\end{tabular}

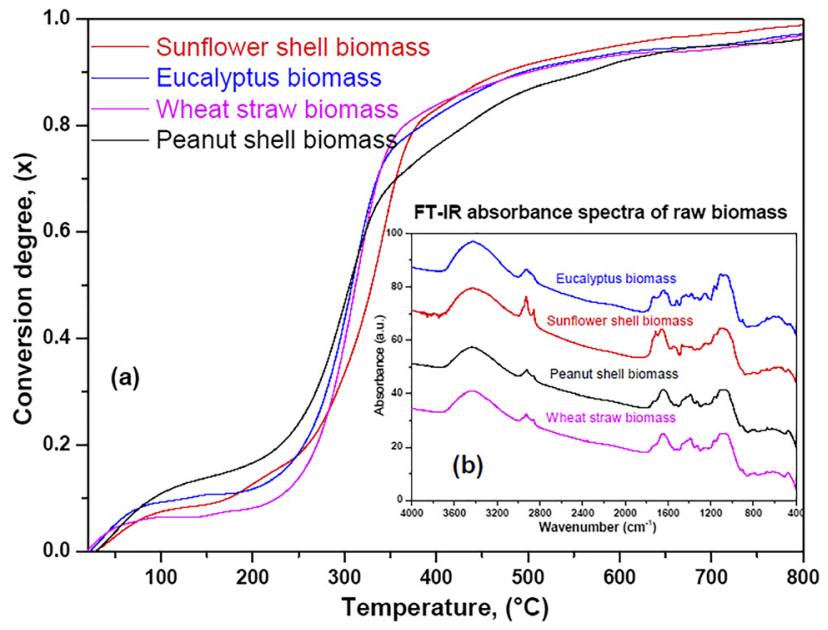

Fig. 9. (a); Conversion degree's variation of SSB, EB, WSB and PSB biomasses, (b); Fourier-transform infrared spectroscopy absorbance spectra of raw biomass 


\section{Pyrolysis of agricultural biomass wastes and product yields}

Several series of experiments were performed to establish the final temperature's effect on pyrolysis products, such as, bio-oil, bio-char and gas products, with a constant heating rate $\left(10^{\circ} \mathrm{C} /\right.$ $\mathrm{min})$, nitrogen flow $\left(100 \mathrm{~mL} \cdot \mathrm{min}^{-1}\right)$, and particle size $(0.1-0.3 \mathrm{~mm})$. Figures 10 and 11 show the plot for effect of temperature $\left(300-700^{\circ} \mathrm{C}\right)$ on pyrolysis products. From these figures, it can be seen that the highest bio-oil yields were 50.05, 46.96, 30.5, and $37.15 \mathrm{wt} \%$, they were obtained from the eucalyptus, sunflower shell, peanut shell, and wheat straw biomasses samples,

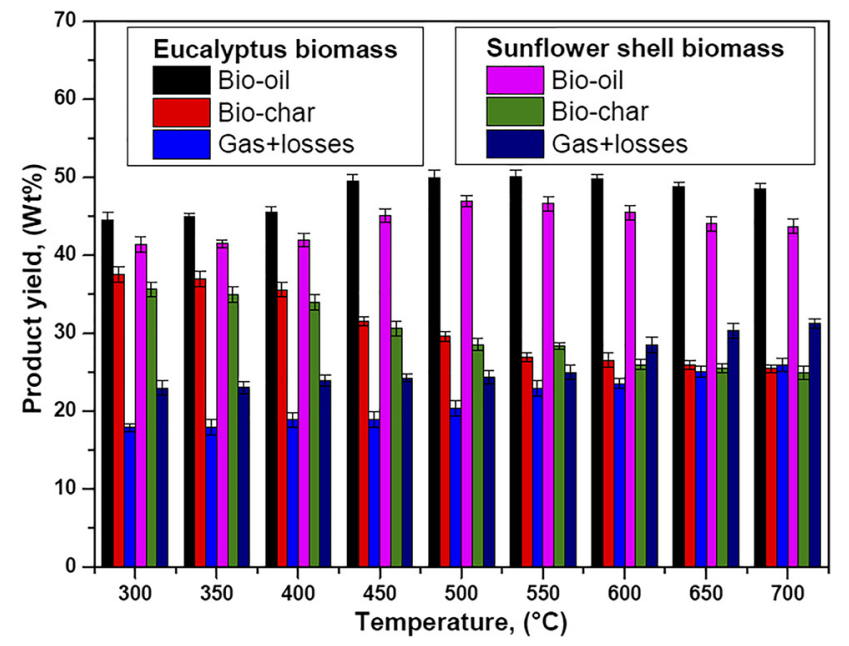

Fig. 10. Liquid, solid and gas' product yields of SSB and $\mathrm{EB}$ at $10^{\circ} \mathrm{C} / \mathrm{min}$

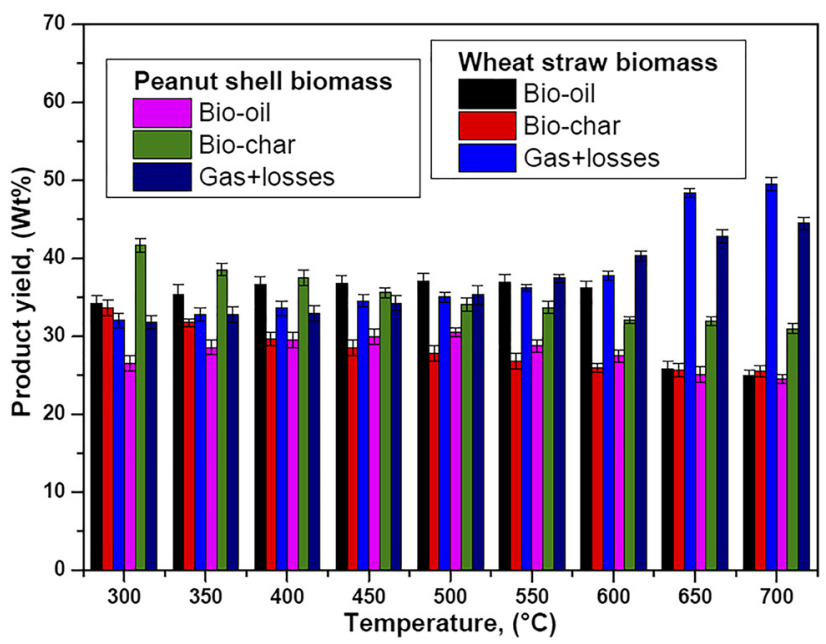

Fig. 11. Liquid, solid and gas product yields of PSB and WSB at $10^{\circ} \mathrm{C} / \mathrm{min}$ 
respectively. The maximums of the bio-oil yields were obtained at the temperature of $550{ }^{\circ} \mathrm{C}$ for $\mathrm{EB}$, and $500^{\circ} \mathrm{C}$ for PSB, SSB and WSB. The yields of bio-oil product augmented with the increase in pyrolysis temperature from $300^{\circ} \mathrm{C}$ to $500-550{ }^{\circ} \mathrm{C}$, and then decreased with the temperature of pyrolysis up to $700^{\circ} \mathrm{C}$. The amount of bio-char obtained from these pyrolysis' experiments of all agricultural biomass samples have decreased. The bio-char yields at $200^{\circ} \mathrm{C}$ were $41.66,33.63,35.62$, and $37.5 \mathrm{wt} \%$ for PSB, WSB, SSB, and EB, respectively. While at $700{ }^{\circ} \mathrm{C}$, bio-char yields were $25.5,31,25$, and $25.5 \mathrm{wt} \%$ for WSB, PSB, EB, and SSB, respectively, at a heating rate of $10{ }^{\circ} \mathrm{C} / \mathrm{min}$. The third products named gas (+losses), generally have increased with increasing of the final temperature of pyrolysis. These results obtained were in agreement with other researches which have been found in literature (Akhtar and Saidina Amin, 2012; Lee et al., 2010; Majhi et al., 2015; Sensoz and Angin, 2008).

Figure 13b shows the degree of conversion from the sunflower shell, eucalyptus, wheat straw and peanut shell biomass samples' pyrolysis in relation to a final temperature of 300 , $350,400,450,500,550,600,650$, and $700^{\circ} \mathrm{C}$ in a stainless steel tubular reactor. As can be seen, the conversion degrees have increased with increasing of the final temperature of pyrolysis. They start from $62.45,63.15,63.45$, and $64.45 \mathrm{wt} \%$ at $200{ }^{\circ} \mathrm{C}$ to $67.48,68.99,75.45$, and $78.45 \mathrm{wt} \%$ at $700{ }^{\circ} \mathrm{C}$, for PSB, WSB, SSB, and EB wastes, respectively. From literature point of view, it has been known that temperature of pyrolysis plays an important and viable role in conversion degree and distribution of bio-oil, bio-char and gas products (Chen et al., 2014; Dai et al., 2019; Duan et al., 2020; Klass et al., 2020; Mullen et al., 2010). At lower temperature, between 100 and $160^{\circ} \mathrm{C}$, agricultural biomass samples lose their moisture, undergo degradation reactions involving no carbohydrate loss, and generate non-combustibles gases like $\mathrm{CO}_{2}$. At temperature higher than $200-250{ }^{\circ} \mathrm{C}$, constituents of biomass samples begin to break. At lower temperature up to $250-350^{\circ} \mathrm{C}$, hemicellulose starts to break down. At temperature between 350 and $500{ }^{\circ} \mathrm{C}$, cellulose breaks down and lignin starts to degrade resulting in water, heavier tars and charcoal. At higher temperatures, reaction of gasification takes place forming hydrogen enriched gaseous products (Guida et al., 2018, 2020; Ozbay et al., 2001).

Both results obtained from pyrolysis of all agricultural biomass wastes in a stainless steel tubular reactor (section "Pyrolysis of agricultural biomass wastes and product yields"), and from thermogravimetric analysis of all samples at $10^{\circ} \mathrm{C} / \mathrm{min}$ (section "Thermal degradation of agricultural biomasses") are mutually reinforcing. And both results of this study are in agreement with several researches on several type of biomass waste (Ioannidou et al., 2009; Phuakpunk et al., 2020; Watt et al., 2020). This allows us to say that agricultural biomass wastes present a good opportunity to create a new renewable source of energy.

\section{Analysis of bio-oil and bio-char products}

Previous studies have been carried out (Biswas et al., 2016; Ceranic et al., 2016; Guida and Hannioui, 2016; Yu et al., 2016), and they have shown that bio-oil obtained from pyrolysis of several types of biomass contains a wide range of complex organic chemicals.

Figures 12 and 13a show the FT-IR and H'NMR analysis of bio-oils obtained from pyrolysis of agricultural biomass samples. As can be seen, the results obtained from pyrolysis of all agricultural biomass samples have a representative FT-IR compared with other and previous works and papers (Duan et al., 2020; Guida and Hannioui, 2016; Guida et al., 2020; 


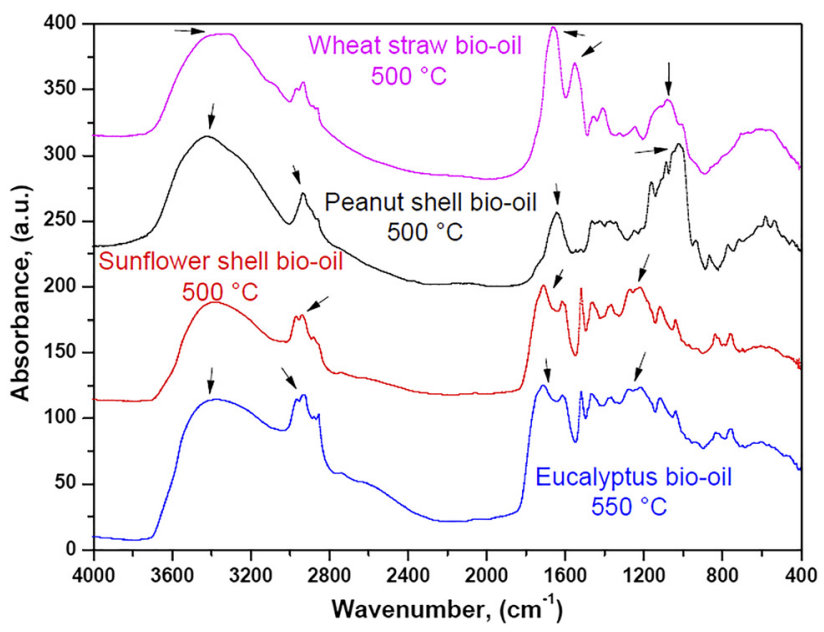

Fig. 12. Fourier-transform infrared spectroscopy absorbance spectra for bio-oils 'liquid product' at optimum condition and at $10^{\circ} \mathrm{C} / \mathrm{min}$

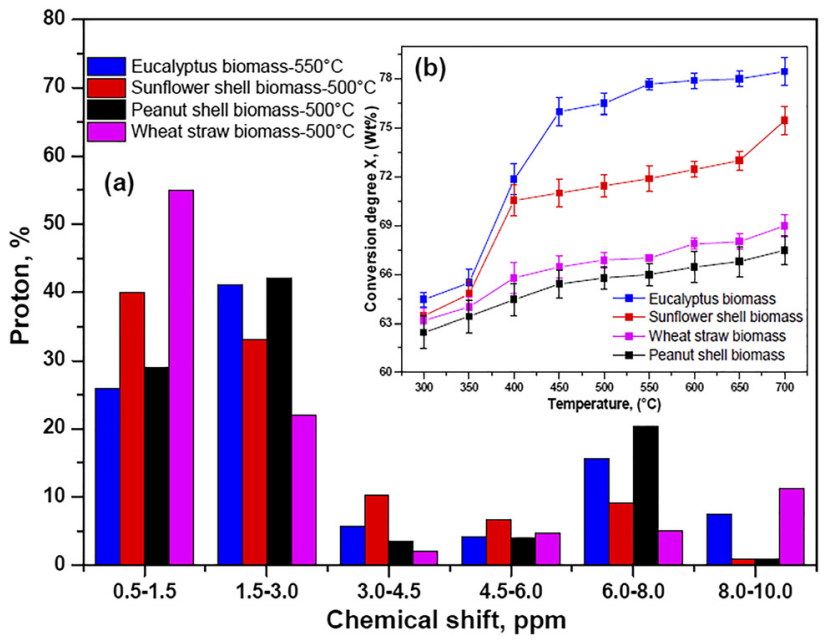

Fig. 13. (a); ${ }^{1} \mathrm{H}$ Nuclear magnetic resonance of EB, SSB, PSB and WSB liquid products at $10^{\circ} \mathrm{C} / \mathrm{min}$, (b); Degree conversion of all waste biomasses

Ioannidou et al., 2009). The FT-IR absorbance spectrum of sunflower shell, eucalyptus, wheat straw and peanut shell's bio-oils show the presence of several and large amounts of products and functional groups in bio-oil samples. The presence of mono- and poly-cyclic and substituted aromatic groups was indicated by the absorption peaks between 600 and $800 \mathrm{~cm}^{-1}$ and 1,400$1,620 \mathrm{~cm}^{-1}$. The absorption peaks between 850 and $1,310 \mathrm{~cm}^{-1}$ indicate the presence of alcohols and phenols compounds and they were shown as the $\mathrm{O}-\mathrm{H}$ bending and $\mathrm{C}-\mathrm{O}$ stretching. The 
presence of aromatics and alkenes functional groups was indicated by the absorbance peaks between 1,610 and 1,640 $\mathrm{cm}^{-1}$ (Guida et al., 2020; Phuakpunk et al., 2020). $\mathrm{C}=\mathrm{O}$ stretching absorbance between 1,640 and $1,740 \mathrm{~cm}^{-1}$ indicates the presence of aldehydes, carboxylic acids and ketones compounds. $\mathrm{C}-\mathrm{H}$ vibrations and $\mathrm{C}-\mathrm{H}$ bending indicated the presence of alkanes, their absorbance was between 2,800 and $300 \mathrm{~cm}^{-1}$, and between 1,350 and $1,470 \mathrm{~cm}^{-1}$. In addition, the absorbance between 3,200 and $3,400 \mathrm{~cm}^{-1}$ have indicated the presence of $\mathrm{O}-\mathrm{H}$ stretching vibration of alcohols and phenols compounds (Serrano et al., 1996). These results from FT-IR analysis have shown that bio-oils from agricultural biomasses' pyrolysis have a high percentage of aliphatic compounds, which means that these bio-oils have an aliphatic character.

With the aim to confirm these results (FT-IR analysis), H'NMR analysis was made on biooils. Figure 13a shows the results of ${ }^{1} \mathrm{H}-\mathrm{NMR}$ of bio-oil (proton \%) obtained at $10^{\circ} \mathrm{C} / \mathrm{min}$, at optimal temperature. As indicated, and additionally to FT-IR analysis, H’NMR analysis confirms the aliphatic character of the bio-oils obtained from pyrolysis of eucalyptus, sunflower shell, wheat straw and peanut shell biomasses (Mullen et al., 2009). As can be seen from Fig. 13a, aliphatic protons' region was represented by chemical shift between 0.5 and $1.5 \mathrm{ppm}$, while protons on aliphatic carbon atoms have been represented by the shift between 1.5 and $3.0 \mathrm{ppm}$, which can be bonded to a $\mathrm{C}=\mathrm{C}$ double bond. Methylene groups which can be joined to aromatic rings and methoxy protons have been represented by the chemical shift between $3.0 \mathrm{ppm}$ and $4.5 \mathrm{ppm}$. All bio-oils obtained at different temperatures $\left(500\right.$ and $\left.550{ }^{\circ} \mathrm{C}\right)$ displayed a percentage of carbohydrate/methoxy functionality, which was represented in 4.5-6.0 ppm region. The aromatic region was represented between $6.0 \mathrm{ppm}$ and $8.0 \mathrm{ppm}$. Furthermore, the downfield spectrum region between 8.0 and $10 \mathrm{ppm}$ of the biomass wastes' bio-oils originates from aldehyde compounds. All bio-oils from agricultural samples at optimal bio-oil temperature showed high aliphatic proton percentages.

Figure 14 shows X-ray diffraction (XRD) of bio-char obtained at $10^{\circ} \mathrm{C} / \mathrm{min}$ from pyrolysis of sunflower shell, eucalyptus, wheat straw and peanut shell biomass waste samples. It can be

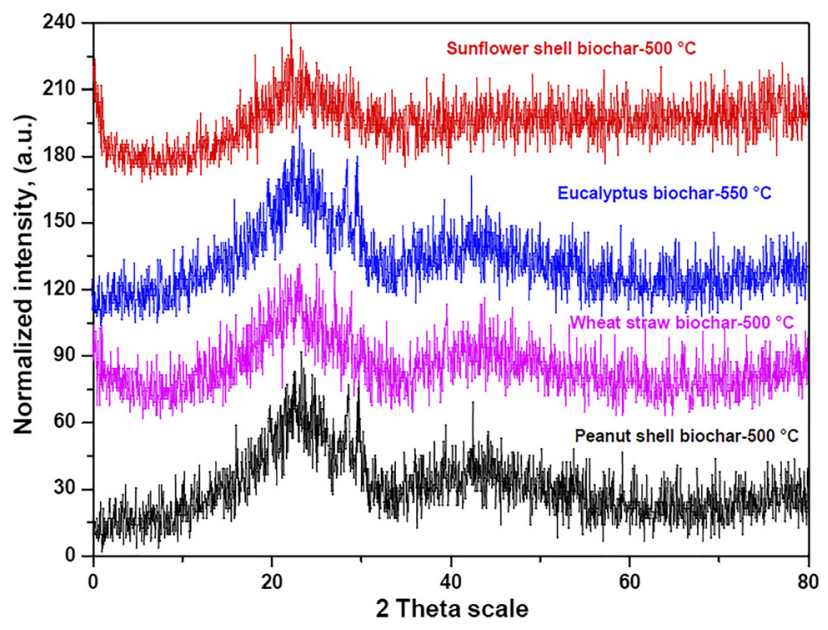

Fig. 14. X-ray powder diffraction of solid product 'bio-char' obtained from pyrolysis of SSB, EB, WSB and PSB 
observed that the bio-char samples have peaks at $2 \theta$ ( 2 Theta) around $21^{\circ}$. This result can be recognized to the crystallographic planes of crystalline regions of cellulose (Meshitsuka and Isogai, 1996). These peaks which appear in the XRD of bio-chars signify the conversion of the cellulose compound in the biomass raw materials. Several studies (Chen et al., 2014; Guida and Hannioui, 2016; Rout et al., 2016), have shown that the peak at 2 theta around $21^{\circ}$ attributed to the cellulose's crystallographic planes has been seen to mitigate with augment in pyrolysis temperature as a result forming amorphous solid product 'bio-char' rich in carbon content. These results obtained from XRD analysis confirm those results obtained from FT-IR analysis, which indicate the formation of products from conversion of raw celluloses (raw biomasses) (Chen et al., 2014; Guida and Hannioui, 2016; Yakub et al., 2015). Similarly, it has been found that the XRD peaks for agricultural bio-chars were characterized by panel bands at the place of cellulose signal representing a destruction of biomass structures and highly muddled structures (Balagurumurthy et al., 2015; Xin et al., 2020).

Elemental analysis of bio-char products obtained from pyrolysis of all types of agricultural biomass waste samples are presented in Table 3. It can be seen from this table that the percentage of carbon content is higher for bio-char and bio-oil in comparison with the original agricultural raw material. It was noticed that carbon percentage in bio-chars was higher than bio-oils products. $\mathrm{H} / \mathrm{C}$ ratios for bio-oils were $1.87,1.95,1.79$, and 1.84 for SSB, EB, WSB, and $\mathrm{PSB}$, respectively, which means that agricultural bio-oils products can be utilized as combustibles and bio-carburant in several domains (0.8-1.7 for heavy fuel and 1.7-1.9 high octane petrol and regular gasoline). Bio-char products have high $\mathrm{HHV}$, they were 23.30, 24.15, 18.44, and $18.4 \mathrm{MJ} / \mathrm{kg}$ for SSB, EB, WSB, and PSB, respectively; and these values were higher than HHVs of bio-oils and biomasses raw materials. Figure 15 presents the carbon, HHVs, hydrogen and oxygen's percentage in relation to the pyrolysis temperature. It can be seen that HHV increased as the final temperature was increased from 300 to $700{ }^{\circ} \mathrm{C}$. This figure shows that carbon content has been increased as the final temperature has risen from 300 to $700{ }^{\circ} \mathrm{C}$, while oxygen and hydrogen contents decreased. These results were in agreement with previous studies made on pyrolysis of several types of biomasses (Guida et al., 2017, 2018, 2020). All results obtained in this research are in coincidence with several works carried out on different biomasses, as indicated in Table 4. From this paper's research, it was concluded that agricultural biomass wastes, such as; sunflower shell, eucalyptus, wheat straw and peanut shell present a good prospective and future renewable energy source for pyrolysis to obtain valuable bio-fuels and bio-chars products.

Table 3. Elemental analysis of bio-oil and bio-char products under nitrogen flow rate at $10^{\circ} \mathrm{C} / \mathrm{min}$ for SSB, $\mathrm{EB}, \mathrm{WSB}$ and PSB

\begin{tabular}{|c|c|c|c|c|c|c|c|c|}
\hline \multirow[b]{2}{*}{ Ultimate analysis (w/w \%) } & \multicolumn{4}{|c|}{ Bio-oil product } & \multicolumn{4}{|c|}{ Bio-char product } \\
\hline & SSB & EB & WSB & PSB & SSB & $\mathrm{EB}$ & WSB & PSB \\
\hline Carbon & 52.06 & 55.18 & 41.01 & 45.66 & 57.12 & 59.05 & 46 & 45.91 \\
\hline Hydrogen & 8.15 & 9.01 & 6.12 & 7.02 & 4.09 & 5.75 & 4.12 & 6.15 \\
\hline $\mathrm{H} / \mathrm{C}^{(\mathrm{a})}$ & 1.87 & 1.95 & 1.79 & 1.84 & 0.85 & 1.16 & 1.07 & 1.6 \\
\hline $\operatorname{HHV}(\mathrm{MJ} / \mathrm{kg})^{(\mathrm{b})}$ & 21.09 & 22.46 & 16.26 & 18.29 & 23.30 & 24.15 & 18.44 & 18.4 \\
\hline
\end{tabular}

(a) Calculated from elemental analysis.

(b) Calculated by formula; HHV =0.4373C-1.6701 (Tillman, 1978). 

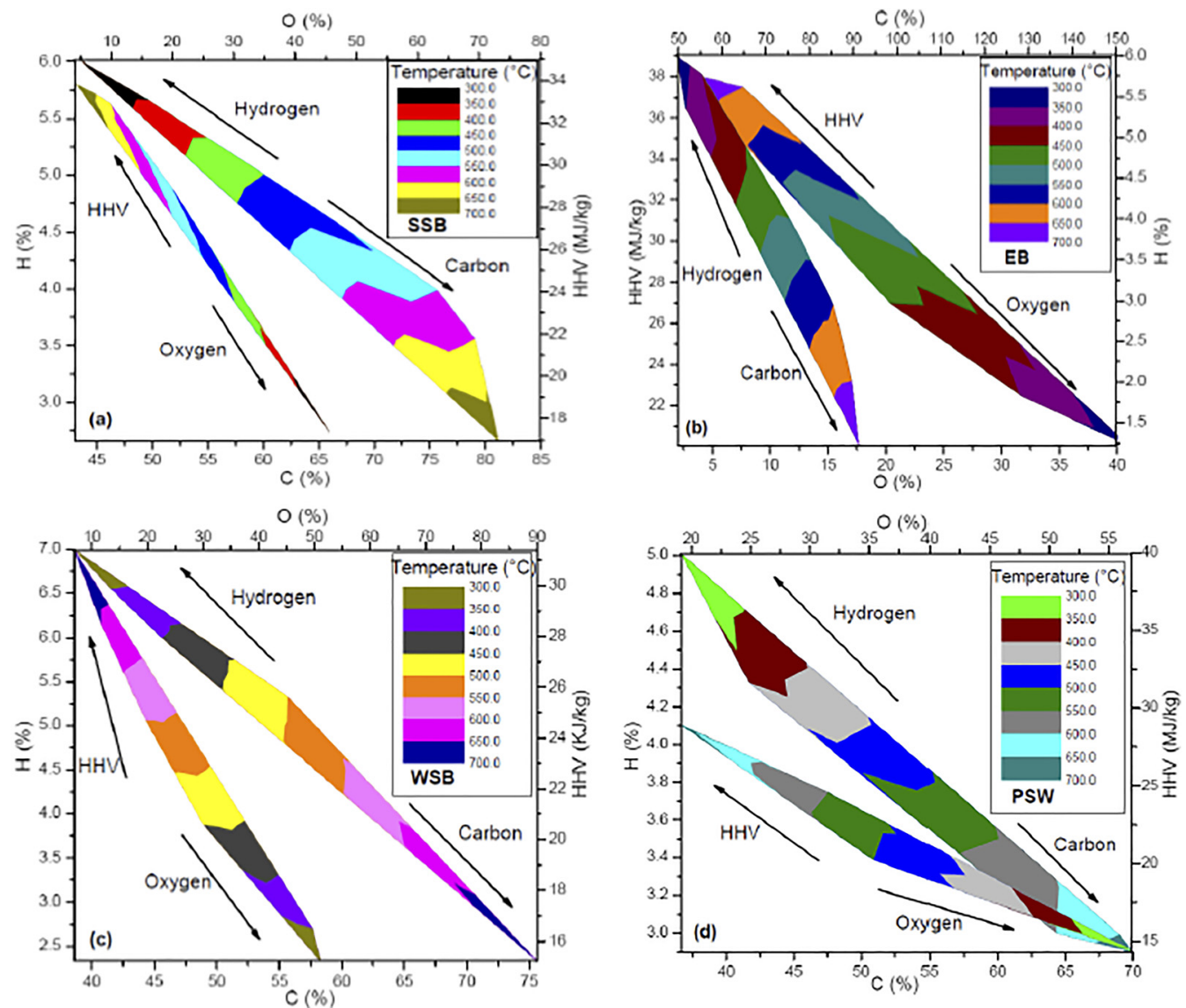

Fig. 15. Higher heating value, oxygen, hydrogen and carbon evolution of solid product 'bio-char' according to the pyrolysis temperature at $10^{\circ} \mathrm{C} / \mathrm{min}$ 
Table 4. Comparative review of different kind of biomass pyrolysis with present work

\begin{tabular}{|c|c|c|c|c|c|}
\hline Biomass & Reactor type & $\begin{array}{c}\text { Temperature } \\
\left({ }^{\circ} \mathrm{C}\right)\end{array}$ & $\begin{array}{l}\text { Heating rate } \\
\left({ }^{\circ} \mathrm{C} / \mathrm{min}\right)\end{array}$ & $\begin{array}{l}\text { Bio-oil yield } \\
\text { (wt \%) }\end{array}$ & References \\
\hline $\begin{array}{l}\text { Sunflower shell } \\
\text { biomass }\end{array}$ & Tubular reactor & 500 & 10 & 46.96 & Present study \\
\hline $\begin{array}{c}\text { Eucalyptus } \\
\text { biomass }\end{array}$ & Tubular reactor & 550 & 10 & 50.05 & \\
\hline $\begin{array}{c}\text { Wheat straw } \\
\text { biomass }\end{array}$ & Tubular reactor & 500 & 10 & 37.15 & \\
\hline $\begin{array}{l}\text { Peanut shell } \\
\text { biomass }\end{array}$ & Tubular reactor & 500 & 10 & 30.50 & \\
\hline Bagasse & $\begin{array}{l}\text { Fixed bed } \\
\text { reactor }\end{array}$ & 500 & 50 & 66.10 & $\begin{array}{c}\text { Asadullah et al. } \\
\text { (2007) }\end{array}$ \\
\hline Wood sawdust & $\begin{array}{l}\text { Semi batch } \\
\text { reactor }\end{array}$ & 500 & 50 & 44.16 & $\begin{array}{l}\text { Kumar Varma } \\
\text { et al. (2019) }\end{array}$ \\
\hline $\begin{array}{l}\text { Jatropha curcas } \\
\text { cake }\end{array}$ & $\begin{array}{l}\text { Fixed bed } \\
\text { reactor }\end{array}$ & 550 & 5 & 45.00 & $\begin{array}{l}\text { Majhi et al. } \\
\text { (2015) }\end{array}$ \\
\hline Napier grass & Intro, heating & 500 & 100 & 35.70 & Lee et al. (2010) \\
\hline $\begin{array}{l}\text { Bifurcaria } \\
\text { bifurcata }\end{array}$ & Tubular reactor & 600 & 5 & 41.30 & $\begin{array}{l}\text { Guida et al. } \\
\text { (2018) }\end{array}$ \\
\hline $\begin{array}{l}\text { Sawdust wood } \\
\text { waste }\end{array}$ & Tubular reactor & 500 & 5 & 39.50 & $\begin{array}{l}\text { Guida et al. } \\
\text { (2020) }\end{array}$ \\
\hline Coconut shell & $\begin{array}{l}\text { Semi batch } \\
\text { reactor }\end{array}$ & 575 & 20 & 49.50 & Rout et al. (2016) \\
\hline $\begin{array}{l}\text { Sunflower seed } \\
\text { press cake }\end{array}$ & $\begin{array}{l}\text { Fixed bed } \\
\text { reactor }\end{array}$ & 500 & 50 & 36.10 & $\begin{array}{c}\text { Sensoz and } \\
\text { Angin (2008) }\end{array}$ \\
\hline $\begin{array}{l}\text { Oil palm } \\
\text { residues }\end{array}$ & $\begin{array}{l}\text { Fixed bed } \\
\text { tubular }\end{array}$ & 600 & 30 & 34.26 & $\begin{array}{l}\text { Yakub et al. } \\
\text { (2015) }\end{array}$ \\
\hline Corn cob & Glass reactor & 450 & 20 & 47.30 & $\begin{array}{c}\text { Biswas et al. } \\
\text { (2017) }\end{array}$ \\
\hline Rice straw & $\begin{array}{l}\text { Lab-scale } \\
\text { pyrolysis reactor }\end{array}$ & 500 & 10 & 43.30 & Park et al. (2014) \\
\hline $\begin{array}{c}\text { Sugar cane } \\
\text { bagasse }\end{array}$ & Tubular reactor & 550 & 5 & 32.80 & $\begin{array}{l}\text { Guida et al. } \\
\text { (2017) }\end{array}$ \\
\hline
\end{tabular}

\section{CONCLUSION}

This study gives fundamental information on the thermal decomposition of sunflower shell biomass, eucalyptus biomass, wheat straw biomass, and peanut shell biomass wastes. The results obtained from this paper can be used in the improvement and enhancement of thermal degradation technologies for agricultural biomass waste, as much as in crucial research on gasification, combustion and liquefaction, since the primary valorization mechanism is common to all these applications except that of liquefaction.

This study has showed that thermogravimetric analysis of all four types of biomasses, such as eucalyptus, sunflower shell, peanut shell, and wheat straw biomasses have been distributed into three stages; drying, main devolatilization and slight devolatilization. The thermochemical decomposition of biomasses was different depending on type of agricultural biomass wastes. 
Present results showed that temperature had a significant effect on bio-oil, bio-char and gas product yields obtained from pyrolysis of agricultural biomass wastes. Maximum bio-oil yields of $50.05,46.96,30.5$, and $37.55 \mathrm{wt} \%$ for $\mathrm{EB}, \mathrm{SSB}, \mathrm{PSB}$, and WSB were obtained at the final temperature of $500{ }^{\circ} \mathrm{C}$ (SSB, PSB, and WSB) and $550^{\circ} \mathrm{C}(\mathrm{EB})$, with a heating rate of $10^{\circ} \mathrm{C} / \mathrm{min}$, a particle size of $0.1-0.3 \mathrm{~mm}$ and a nitrogen flow rate of $100 \mathrm{~mL} \cdot \mathrm{min}^{-1}$. Bio-oil and bio-char products obtained were analyzed using several physico-chemical and analytical methods. The results show that both products have interesting properties and can be used as renewable sources of energy.

\section{ACKNOWLEDGMENTS}

All thanks are addressed to the director, laboratory of organic and analytical chemistry (LCOA), Béni-Mellal, Morocco, for his invaluable support in this work from a financial and material point of views. And great thanks have been addressed to: Pr. Mr. A. Hannioui, Pr. Mr. E. M. Rakib, and Pr. Mr. A. Medaghri-alaoui, professors of education, members of educational committee of chemistry and environment department, Faculty of Sciences and Techniques, University of Sultan Moulay Slimane, for their encouragement and support during the course of this interesting work.

\section{REFERENCES}

Akhtar, J. and Saidina Amin, N. (2012). A review on operating parameters for optimum liquid oil yield in biomass pyrolysis. Renewable \& Sustainable Energy Reviews, 16: 5101-5109.

Asadullah, M., Rahman, M. A., Ali, M. M., Rahman, M. S., Morin, M. A., Sultan, M. B., and Alam, M. R. (2007). Production of bio-oil from fixed bed pyrolysis of bagasse. Fuel, 86: 2514-2520.

Balagurumurthy, B., Srivastava, V., Vinit Kumar, J., Biswas, B., Singh, R., Gupta, P., Kumar, S.K.L.N., Singh, R., and Bhaskar, T. (2015). Value addition to rice straw through pyrolysis in hydrogen and nitrogen environments. Bioresource Technology, 88: 273-279.

Bayramzadeh, S. and Aghaei, P. (2020). Technology integration in complex healthcare environments: a systematic literature review. Applied Ergonomics, 92: 103351.

Benedek, J., Sebestyen, T.T., and Bartok, B. (2018). Evaluation of renewable energy sources in peripherial areas and renewable energy based rural development. Renewable \& Sustainable Energy Reviews, 90: 516-535.

Biswas, B., Singh, R., Kumar, J., Khan, A.A., Krishna, B.B., and Bhaskar, T. (2016). Slow pyrolysis of prot, alkali and dealkaline lignins for production of chemicals. Bioresource Technology, 213: 319-326.

Biswas, B., Singh, R., Kumar, J., Khan, A. A., Krishna, B. B., and Bhaskar, T. (2017). Slow pyrolysis of prot, alkali and dealkalinelignins for production of chemicals. Bioresource Technology, 213: 319-326.

Ceranic, M., Kosanic, T., Djuranovic, D., Kaludjerovic, Z., Djuric, S., Gojkovic, P., and Bozickovic, R. (2016). Experimental investigation of corn cob pyrolysis. Journal of Renewable and Sustainable Energy, http://dx.doi.org/10.1063/1.4966695.

Chen, Z., Hu, M., Zhu, X., Guo, D., Liu, S., Hu, Z., Xiao, Bo., Wang, J., and Laghari, M. (2015). Characteristics and kinetic study on pyrolysis of five lignocellulosic biomass via thermogravimetric analysis. Bioresource Technology, 192: 441-450. 
Chen, G., Liu, C., Ma, W., Zhang, X., Li, Y., Yan, B., and Zhou, W. (2014). Co-pyrolysis of corn cob and waste cooking oil in a fixed bed. Bioresource Technology, 166: 500-507.

Dai, L., Zeng, Z., Tian, X., Jiang, L., Yu, Z., Wu, Q., Liu, Y., and Ruan, R. (2019). Microwave-assisted catalytic pyrolysis of torrefied corn cob for phenol-rich bio-oil production over Fe modified bio-char catalyst. Journal of Analytical and Applied Pyrolysis, 143: 104691.

Demiral, I. and Ayan, E.A. (2011). Pyrolysis of grape bagasse: effect of pyrolysis conditions on the product yields and characterization of the liquid product. Bioresource Technology, 102: 3946-3951.

Dostal, Z. and Ladanyi, L. (2018). Demands on energy storage for renewable power sources. Journal of Energy Storage, 18: 250-255.

Duan, D., Zhang, Y., Wang, Y., Lei, H., Wang, Q., and Ruan, R. (2020). Production of renewable jet fuel and gasoline range hydrocarbons from catalytic pyrolysis of soapstock over corn cob-derived activated carbons. Energy, 209: 118454.

Erdil, A. and Erbijik, H. (2015). Renewable energy sources of Turkey and assessment of sustainability. Procedia-Social and Behavioral Science, 207: 669-679.

Guida, M.Y. (2017). Bio-oil and bio-char feedstocks from pyrolysis of olive mill wastes, such as; olive mill solid waste and olive mill wastewater. India. Journal of Environmental Protection, 37(8): 632-646.

Guida, M.Y., Bouaik, H., EL Mouden, L., Moubarik, A., Aboulkas, A., El Harfi, K., and Hannioui, A. (2017). Utilization of starink approach and avrami theory to evaluate the kinetic parameters of the pyrolysis of olive mill solid waste and olive mill wastewater. Journal of Advanced Chemical Engineering, 7: 1-8.

Guida, M.Y., Bouaik, H., Tabal, A., Hannioui, A., Solhy, A., Barakat, A., Aboulkas, A., and El harfi, K. (2015). Thermochemical treatment of olive mill solid waste and olive mill wastewater: kinetic study. Journal of Thermal Analysis and Calorimetry, 123: 1657-1666.

Guida, M.Y. and Hannioui, A. (2016). A review on thermochemical treatment of biomass: pyrolysis of olive mill wastes in comparison with other types of biomass Progress in. Agricultural Engineering Sciences, 12(1): 1-23.

Guida, M.Y., Laghchioua, F.E., and Hannioui, A. (2018). Pyrolysis of brown algae (bifurcariabifurcata) in a stainless steel tubular reactor: from a review to a case study. Progress in Agricultural Engineering Sciences, 14: 31-60.

Guida, M. Y., Lanaya, S. E., Laghchioua, F. E., Rbihi, Z., and Hannioui, A. (2020). Production of bio-oil and bio-char from pyrolysis of sawdust wood waste (SWW). Progress in Agricultural Engineering Sciences, 16(1): 61-80.

Guida, M.Y., Lanaya, S.E., Rbihi, Z., and Hannioui, A. (2019). Thermal degradation behaviors of sawdust wood waste: pyrolysis kinetic and mechanism. Journal of Materials and Environmental Science, 10(8): 742-755.

Heo, H.S., Park, H.J., Park, Y.K., Ryv, E., Suh, D.J., Suh, Y.W., Yim, J.H., and Kim, S.S. (2010). Bio-oil production from fast pyrolysis of waste furniture sawdust in a fluidized bed. Bioresource Technology, 101: S91-S96.

Huang, Y.F., Chiueh, P.T., and Lo, S.L. (2016). A review on microwave pyrolysis of lignocellulosic biomass. Sustainable Environment Research, 26(3): 103-109.

Ioannidou, O., Zabaniotou, A., Antonakou, E. V., Papazisi, K. M., Lappas, A. A., and Athanassiou, C. (2009). Investigating the potential for energy, fuel, materials and chemicals production from corn residues (cobs and stalks) by non-catalytic and catalytic pyrolysis in two reactor configurations. Renewable and Sustainable Energy Reviews, 13: 750-762.

Khan, H., Khan, I., and Tienbinh, T. (2020). The heterogeneity of renewable energy consumption, carbon emission and financial development in the globe: a panel quantile regression approach. Energy Reports, 6: 859-867. 
Klaas, M., Greenhalf, C., Ouadi, M., Jahangiri, H., Hornung, A., Briens, C., and Berruti, F. (2020). The effect of torrefaction pre-treatment on the pyrolysis of corn cobs. Results in Engineering, 7: 100165.

Kumar, R., Gera, P., Jha, M. K., and Bhaskar, T. (2018). Pyrolysis kinetics and thermodynamic parameters of castor (Ricinuscommunis) residue using thermogravimetric analysis. Bioresource Technology, 250: $422-8$.

Kumar, R., Strezov, V., Weldekidan, H., He, J., Singh, S., Kan, T., and Dastjerdi, B. (2020). Lignocellulosic biomass pyrolysis for bio-oil production: a review of biomass pre-treatment methods for production of drop in fuels. Renewable and Sustainable Energy Reviews, 123: 109763.

Kumar Varma, A., Thakur, L. S., Shankar, R., and Mondal, P. (2019). Pyrolysis of wood sawdust: effects of process parameters on products yield and characterization of products. Waste Management, 89: 224-235.

Lee, M.K., Tsai, W.T., Tsai, Y.L., and Lin, S.H. (2010). Pyrolysis of napier grass in an introduction heating reactor. Journal of Analytical and Applied Pyrolysis, 88(2): 110-116.

Liew, J. X., Minh Loy, A. C., Fui Chin, B. L., Ainouss, A., Shahbaz, M., Al-Ansari, T., Govindan, R., and Chai, Y. H. (2021). Synergistic effects of catalytic co-pyrolysis of corn cob and HDPE waste mixtures using weight average global process model. Renewable Energy, 170: 948-963.

Majhi, A., Sharma, Y.K., Naik, D.V., and Chauchan, R. (2015). The production and evaluation of bio-oil obtained from the jatrophacurcas cake. Energy Sources Part A Recovery Utilization and Environmental Effects, 37(16): 1782-1789.

Malakar, A., Kanel, S. R., Ray, C., Snow Daniel, D., and Nadagouda, M. N. (2021). Nanomaterials in the environment, human exposure pathway, and health effects: a review. Science of Total Environment, 759: 143470.

Meshitsuka, G. and Isogai, A. (1996). Chemical structures of cellulose, hemicellulose and lignin. In: Hon, D.N. (Ed.), Chemical modification of lignocellulosic materials. Marcel Dekker Inc., New York, pp. 11-34.

Minkova, V., Razvigorova, M., Bjornbom, E., Zanzi, R., Budinova, T., and Petrov, N. (2001). Effect of water vapour and biomass nature on the yield and quality of pyrolysis products from biomass. Fuel Processing Technology, 70: 53-61.

Moham, D., Pittman, C.U., and Steel, P.H. (2006). Pyrolysis of wood/biomass for bio-oil: a critical review. Energy \& Fuels, 20: 848-889.

Mullen, C. A., Boateng, A. A., Goldberg, N. M., Lima, I. M., Laird, D. A., and Hicks, K. B. (2010). Bio-oil and bio char production from corn cobs and stover by fast pyrolysis. Biomass and Bioenergy, 34: 67-74.

Mullen, C.A., Strahan, G.D., and Boateng, A.A. (2009). Characterization of various fast pyrolysis bio-oils by NMR spectroscopy. Energy Fuels, 23: 2707-2718.

Ozbay, N., Putun, A.E., Uzun, B.B., and Putun, E. (2001). Biocrude from biomass: pyrolysis of cottonseed cake. Renewable Energy, 24(3-4): 615-625.

Park, J., Lee, Y., Ryu, C., and Park, Y.K. (2014). Slow pyrolysis of rice straw: analysis of products properties, carbon and energy yields. Bioresource Technology, 155: 63-70.

Parthasarathy, P. and Narayanan, S. (2015). Effect of combined slow pyrolysis and steam gasification of sugar cane bagasse on hydrogen generation. Korean Journal of Chemical Engineering, 32: 2236-2246.

Phuakpunk, K., Chalermsinsuwan, B., and Assabumrungrat, S. (2020). Comparison of chemical reaction kinetic models for corn cob pyrolysis. Energy Reports, 6: 168-178.

Pimenta, A.S., Da Costa Monteiro, T.V., Fasciohi, M., Braga, R.M., De Souza, E.E., and De lina, K.M.G. (2018). Fast pyrolysis of trunk wood and stump wood from a Brazilian eucalyptus clore. Industrial Crops and Products, 125: 630-638. 
Rout, T., Pradhan, D., Singh, R. K., and Kumari, N. (2016). Exhaustive study of products obtained from coconut shell pyrolysis. Journal of Environmental Chemical Engineering, 4: 3696-3705.

Searcy, E. and Flynn, P.C. (2010). A criterion for selecting renewable energy process. Biomass \& Bioenergy, 34(5): 798-804.

Sensoz, S. and Angin, D. (2008). Pyrolysis of safflower (charthamustinctorius L.) seed press cake: part 1, the effects of pyrolysis parameters on the product yields. Bioresource Technology, 99: 5492-5497.

Sensoz, S., Demiral, I., and Gercel, H.F. (2006). Olive bagasse (oleaeuropa L.) pyrolysis. Bioresource Technology, 97: 429-436.

Serrano, V.G., Villegas, J.P., Florindo, A.P., Valle, C.D., and Calahorro, C.V. (1996). FT-IR study of rockrose and of char and activated carbon. Journal of Analytical and Applied Pyrolysis, 36: 71-80.

Shang, H., Du, W., Liu, Z., and Zhang, H. (2013). Development of microwave induced hydrodesulfurization of petroleum streams: a review. Journal of Industrial and Engineering Chemistry, 19(4): 1061-1068.

Situmorang, Y. A., Zhao, Z., Chaihad, N., Wang, C., Anniwaer, A., Kassai, Y., Abudula, A., and Guand, G. (2021). Steam gasification of co-pyrolysis chars from various types of biomass. The International Journal of Hydrogen Energy, XX: 1-11.

Tillman, D.A. (1978). Chap III. The value of wood as a fuel wood as an energy resource. New York: Academic press, pp. 65-87.

Uzun, B.B., Putun, A.E., and Putun, E. (2007). Composition of products obtained via fast pyrolysis of olive oil residue: effect of pyrolysis temperature. Journal of Analytical and Applied Pyrolysis, 79: 147-153.

Varma, A.K., Thakur, L.S., Shankar, R., and Mondal, P. (2019). Pyrolysis of wood sawdust: effects of process parameters on products yield and characterization of products. Waste Management, 89: 224-235.

Watt, E., Abdelwahab, M. A., Mohanty, A. K., and Misra, M. (2020). Biocomposites from biobased polyamide 4, 10 and waste corn cob based bio-carbon. Composites. JCOMA.

Worasuwannarak, N., Sonobe, T., and Tanthapanichakoon, W. (2007). Pyrolysis behaviors of rice straw, rice husk, and corncob by TG-MS technique. Journal of Analytical and Applied Pyrolysis, 78: 265-271.

Xiao, Y., Pudasainee, D., Gupta, R., Xu, Z., and Diao, Y. (2017). Bromination of petroleum coke for elemental mercury capture. Journal of Hazardous Materials, 33b: 232-239.

Xin, X., Dell, K., Udugama, I. A., Young, B. R., and Baroutiau, S. (2020). Transforming biomass pyrolysis technologies to produce liquid smoke food flavouring. Journal of Cleaner Production, XX: 1-12.

Yakub, M. I., Abdalla, A. Y., Feroz, K. K., Suzana, Y., Ibraheem, A., and Chin, S. A. (2015). Pyrolysis of oil palm residues in a fixed bed tubular reactor. Journal of Power and Energy Engineering, 3: 185-193.

Yang, H., Yan, R., Chen, H., Lee, D.H., Liang, D.T., and Zheng, C. (2006). Mechanism of palm oil waste pyrolysis in a packed bed. Energy Fuels, 20: 1321-1328.

Yanting, Z. and Liyun, X. (2011). Research on risk management of petroleum operations. Energy Procedia, 5: 2330-2334.

Yu, M., Chen, Z., Wang, S., Guo, D., Ma, C., Zhou, Y., Chen, J., Laghari, M., Fazal, S., Xiao, B., Zhang, B., and Ma, S. (2016). Thermogravimetric kinetics of lignocellulosic biomass slow pyrolysis using distributed activation energy model, Fraser-Suzuki deconvolution, and iso-conversional method. Energy Convers Manage, 2016(118): 1-11.

Zabaniotou, A.A. (2010). Pyrolysis of forestry biomass by-products in Greece. Energy Sources, 21: 395-403.

Open Access. This is an open-access article distributed under the terms of the Creative Commons Attribution-NonCommercial 4.0 International License (https://creativecommons.org/licenses/by-nc/4.0/), which permits unrestricted use, distribution, and reproduction in any medium for non-commercial purposes, provided the original author and source are credited, a link to the CC License is provided, and changes - if any - are indicated. 